TEXT Special Issue 46 (October 2017)

\title{
Poems contents
}

- PQR Anderson page 2

- Cassandra Atherton page 8

- Owen Bullock page 9

- Anne Caldwell page 10

- Monica Carroll page 11

- Justin Clemens page 12

- Oliver Comins page 14

- Jennifer Crawford page 15

- Lucy Dougan page 16

- Carrie Etter page 17

- Niloofar Fanaiyan page 18

- Ross Gibson page 19

- Stephanie Green page 20

- Charlotte Guest page 21

- Oz Hardwick page 22

- Dominique Hecq page 23

- Paul Hetherington page 24

- Penelope Layland page 25

- Rupert M Loydell page 26

- Nigel McLoughlin page 27

- Andrew Melrose page 28

- Paul Munden page 29

- Alvin Pang page 30

- Maggie Shapley page 31

- Julian Stannard page 32

- Shane Strange page 33

- Jen Webb page 34

- Jordan Williams page 35 


\section{University of Cape Town}

\section{PQR Anderson}

\section{Three poems}

Biographical note:

PQR Anderson is the author of two volumes of poetry, Litany Bird and Foundling's Island, and editor of the anthology In the Country of the Heart (South African love poetry). Most recently, he was the runner-up in the 2016 University of Canberra's Vice-Chancellor's International Poetry Prize. He lectures in English Literature at the University of Cape Town. 


\section{On Arrival}

1

And as into life fall from the CO.TRA.L bus

into the storm. Water shreds the forests.

Every darkness is swollen, a black pulp

pushing through prepositions - under, between -

as a kingdom come. Climb to the light

by the wuthering of a TV in another room, random

as wrong wiring, wet as electricity, follow

shoes in tea, the hairpins, out of the cloud.

\section{2}

What is hail more like: barley or polystyrene?

Kick it into corners among the oleander;

it will keep its own company. Tread on purpose

on the lethal tiles, towel, put your pith feet

in the window to air. The martins come down

from the cliffs of S. Nicolo di Bari, a thousand

socks in the wake of the weather. And plastic

tables are drawn like a jet across the cobbles to dry.

3

Wipe your chair with a waiter's clout and wait, who is also served. Across the cobbles watch

water through watered air. And an embarrassed sun. A dark you can no longer see bows you down

at the fosses where your brain is loam, sheds water out of sight. All's well at those wells, you

feel, your face untangling storm air and sunlight. Torn hills and phosphates, coffee, dark stuff. 
4

Here in its emergence the unseen is almost seen: water off a crow's back, the sigh of entire hills.

A yeast of beetles riddles the surface, and buzzards are sucked after the storm in their hope of leavings,

like your notebook, dragged in the swept damp, speechless in an evacuated now. West towards

Rome the light blossoms in the cinema of itself, staggering in barns of clouds, mixing metaphors.

\section{5}

Put it this way, since you, too, flourish under the mask of oxygen put to you: in that

brighter half-hour, undrenched, has not the crow flown to your shoulder, the finch unthrottled on the cemetery millstone? Surely the ditch-borne bark of a boar has travelled every marrow in the valley, and are you not fallen, and for it? Light's the colour of your coin.

Roccagiovine, 2014 


\section{Goldfinches}

Remind us: the welder's hose of damp fire, the sleeve of sparks worn where a chisel's ground.

They chase themselves through some far other day high over the recycling bins, the tar

panhandle where the one bus burns an hour, to decorate the tall fir at the shrine

of San Pio painted bronze, whose plastic flowers fail like the real. Scarred with a sergeant's gold

they fold in the dark needles. Flakes of light, then gone. Spores of mistletoe. Suds of ash.

Who grinds out their accidental spark, laying what chisel to what wheel? What torch

cuts their share of its blue daylight, welds us to the pavement that they escape? You tread

the planet round and then you write them down in faithless ink and find yourself in hope

of striking sparks. You find that you are watched at that same window on which you both depend:

now eavesdropped there, it discovers you gold -Apollo's tiny eagle landed.

\section{Coda}

And of that red regard? Only the probable origin of all signs, all signaturethe trauma of platonic ink, so potent it needs no alphabet to state what once written is still read: being's emergency.

Roccagiovine, 2008 


\section{Out of the Wind}

\section{Black South-Easter}

The common street, drubbed nightlong by our particular wind reared on a pointless south Atlantic, whose birds office its rigging, as here the brawling gulls, juggled in light,

where shopping goes and Summer comes, surprised at its own arrival, flung out of the first of sleepless nights in a rain no more than a clawed cloud, to hang its wing on the Black River's sump slung under freeways, flamingos siphoning a swart silt in lagoons contrived by the wadered Council among hectares of water hyacinth, its green candles

receiving like a lung, where tins blink, speech gutters in gutters where grit's winnowed and oil drawn, here you forget again what it was you meant to, and why it seemed so.

\section{In the Trances of the Blast}

October, lying

out on the roof, nights,

I heard the caterpillars

take down a tree.

When the wind held off.

The stars stopped

in their great mess

for me and dwelt away, actually there and so

far as not to be.

The scratching worms, the blistered sky.

\section{Eight Days of Continuous Wind}

Now is the nothing world, shorn by air, scoured by ego-less light till the coins in our eyes carry no face. Should we be glad of this resumption in glare, careless 
of hope in a hopeless morning, hammered to the wind, the light billowing and collapsing in it, rubbed out? Time shinnies like a car going to things, battened

to now, where nothing is happening but the only inevitable succession of itself, like a body, and the next forgets its begetting. A packet resurrects

a moment, wanting so say something about being, falls to a wheel and is dragged there for as long as we mark time by it, goes wide in the width of the gale. 


\section{Deakin University}

\section{Cassandra Atherton}

Prose poems, written by members of the Prose Poetry Project, November 2014 to July 2017, compiled by the editors

Biographical note:

Cassandra Atherton is an award-winning writer, academic and critic. She has written eight books (with two more in progress) and has been awarded a Harvard Visiting Scholar ${ }^{1} \mathrm{~s}$ position from 2015-2016. http://cassandraatherton.com

Blue twilight unfurls its splendour, a Didionesque gloaming for the lonely. I try to catch its tint in my cup, to taste its calm, but its inkiness spills over me until I am glass. Bathed in owl-light, I float on short blue wavelengths. I cannot be broken.

(from Pulse 2016) 


\section{University of Canberra}

\section{Owen Bullock}

Prose poems, written by members of the Prose Poetry Project, November 2014 to July 2017, compiled by the editors

Biographical note:

Owen Bullock's publications include urban haiku (Recent Work Press, 2015), breakfast with epiphanies (Oceanbooks, NZ, 2012) and sometimes the sky isn't big enough (Steele Roberts, NZ, 2010). He won the Canberra Critics' Circle Award for Poetry 2015. He has recently completed a PhD Candidate in Creative Writing at the University of Canberra.

He didn't provide. He smacked his daughter one time and bent her finger back. He shared blame for 9/11 the world had not evolved towards peace, he had not evolved.

(from Seam 2015) 


\title{
University of Bolton
}

\author{
Anne Caldwell
}

Prose poems, written by members of the Prose Poetry Project, November 2014 to July 2017, compiled by the editors

Biographical note:

Anne Caldwell is a poet, lecturer in creative writing at the University of Bolton in the UK, and Deputy Director of the National Association for Writers in Education (NAWE). Her latest poetry collection is Talking with the Dead (Cinnamon, 2011).

And this dim-lit life is a glass vase in the making. Needs blowing and warming. She loads her rod with molten liquid from the furnace, rolling the orange glow at over 900 degrees in wet newspaper, until life begins to cool a little and harden. She doesn't wear gloves, dips it in powdered cobalt. She blows, then places her thumb over the rod until the glass begins to swell into a bauble, catching that air-bubble at its centre. Keep turning. Keep blowing. Find life's heat. Don't stop moving.

(from tract 2017) 


\title{
University of Canberra
}

\author{
Monica Carroll
}

Prose poems, written by members of the Prose Poetry Project, November 2014 to July 2017, compiled by the editors

Biographical note:

Monica Carroll holds a PhD in philosophy and poetry. She is a Donald Horne Creative and Cultural Fellow for the Centre for Creative and Cultural Research. Her academic publications include papers on poetry, space and writing. Her research interests include phenomenology, poetry and empathy. Her widely published experimental prose and poetry includes the book Isolator (Recent Work Press 2017).

This is the dress of my drowning. Like pebbles in the pits and pearls in the tide, my colours only sing when submerged. I tack pieces to the toile, worn as I sew, stitching myself in. The fabric is harsh on my hands. Cutting. Each pattern piece a layer of silk under shards of clear diamond, sea sapphire, blood garnet. Every stone gaoled by a silk cross stitch. Amethyst, the tint of lightning at twilight. Emeralds, green as Spring's aggression. My hands milked as I suture my body into heavy beauty. The Haberdasher promised this blackiron buckle the weightiest. I baste it to the waist of gold-laced rick-rack. I tend to shirring on the upper sleeves, puck the gusset underneath, pleat the bodice, so I will fill. Swell. Dark silver braid at the cuffs. Godets inside godets and the skirts are flat felled seamed with sand pressed into the join. Raw edges masked. My collar stays are lead. I will float low to the silt shelf bottom and settle. Shining. Each basted ruby stealing its moment to capture the shifting sun and blaze through black.

(from Seam 2015) 


\section{University of Melbourne}

\section{Justin Clemens}

\section{Let us wreak all the extraordinary scene: Organs!}

\section{Biographical note:}

Justin Clemens is the author of poetry books such as Villain (Hunter 2009), me 'n' me trumpet (Vagabond 2011) and The Mundiad (Hunter 2013). Other recent works include What is Education? (Edinburgh University Press 2017), edited with A.J. Bartlett, and The Afterlives of Georges Perec (Edinburgh University Press 2017), edited with Rowan Wilken. He is an Associate Professor at the University of Melbourne. 
Fag go cite yer happendicks my fare lardy far licked as hick may pee hit mean not pore lea oh all those puck masts and booty spits knot wit staining. It's the spermatozoa that makes the mane rafter hall, haunted tit as yew sea. Ware the fuckundertitty of punis yea the rayer for lone don streets et frites Hamon L'Estrange vaping foyer waxing lonely. Yet won dare fool hun dear thee reign. Wowser and Hurt, purveyors of faux monnaies, covered tee bee lee tea, wit out con urchin, dom hectic butchery of the kitchen, every pea an encounter with this equine valency of fats and smuts, one severed book head hooded with its own stocking face dissing the twerky twisty visages of Verdopplung and Doppelsinn, twin lawyers, who look so same-old same-old they can't tell themselves apart, just ass homotopy siting well, hoot siding the in very ants tomographic spliffs. Way out in two species in semi nation he limn and ate court ship time by circus vaunting the mating plug pen till Mal gets a nutrient rich me. For please his limy toad today's spa at temps to tote foe fruits farced by a dubble doze of insoluble soul orphically jury dicing de hearth, an elegy for mew chew ally redo sibyl strictures and - fie! - nearly a meaning: the ongoing damage precipitated by my hex is tense and cannot be vitiated by any possible good that might be done by it. Yo ho ho oh - separate the subject from its predicates: the posthumous from its quantities: the anonymous from its lack: the lack of name from its piquancy: WE DO NOT AIM TO CONSERVE THE SAME SEMANTICS: a vain or vein or vane seen blown against the wall skin glossy as a serried amour big host by a student homophone of herself despite the mauvais bi lite sprogged by that thyme wen birds drop dead from the dad eyed branches deploring the mantic spore of the ancient lore fuckering da sire wit a ludic shine and ten-ton twotone valley tan droning tween roar and drowse sans metro apriorosity or aporiosity, i.e., Translated by Shirley, Curley, Burley, and Whirly, then pushed out the bock dour at the Bore's Ed Pub, engendering the same and different equivocally and simultaneously like endogamous moulting probabilities preended for munificent proliferating monotremic polynomians ugh. ps the striation buck is using is not the essence of nature as such. 


\section{Oliver Comins}

Prose poems, written by members of the Prose Poetry Project, November 2014 to July 2017, compiled by the editors

\section{Biographical note:}

Oliver Comins lives and works in West London. His early poetry is collected in Playing Out Time in an Awkward Light (Mandeville Press) and Anvil New Poets Two (ed. Carol Ann Duffy). A short collection (Yes to Everything) won a Templar Portfolio Award in 2014. His latest collection Staying in Touch is published by Templar Poetry (2015).

No-one's heart in that room is waiting to be broken for the first time and no-one is standing here among the quiet men whose long souls have begun to shrink in a genteel manner. Scars healing create the same effect, by slow tightening as the first wound begins to dry. In another place, to which reference was made earlier, cardiographic studies have shown how hearts not damaged are so rare it is quite possible that, statistically speaking, they may not exist at all.

(from Pulse 2016) 


\section{University of Canberra}

\section{Jennifer Crawford}

Prose poems, written by members of the Prose Poetry Project, November 2014 to July 2017, compiled by the editors

Biographical note:

Jen Crawford's poetry publications include 3 (Five Islands Press, 2000), Bad Appendix (Titus Books, 2008), Pop Riveter (Pania Press, 2011) and Koel (Cordite Books, 2016). She is an Assistant Professor of Creative Writing at the University of Canberra.

the social work intern is surprised that the youths must squat to greet visitors to the centre. the shock puts him in a sombre mood.

the social work intern has an immediate sense of the loss of dignity among the youths when he sees them squatting at toilets in full view of the staff.

the social work intern arranges a game of crab soccer. he want to slow the youths' dynamics so he can observe them more closely. he's here to learn. everyone on their hands and knees.

(from Seam 2015) 


\section{Curtin University}

\section{Lucy Dougan}

Prose poems, written by members of the Prose Poetry Project, November 2014 to July 2017, compiled by the editors

Biographical note:

Lucy Dougan's books include Memory Shell (Five Islands Press), White Clay (Giramondo), Meanderthals (Web del Sol) and The Guardians (Giramondo), and her prizes the Mary Gilmore Award, the Alec Bolton Award and shortlistings for the 2015 Queensland Premier's Prize for Poetry and the 2016 Victorian Premier's Prize for Poetry. She currently works for Westerly at UWA and also teaches creative writing at Curtin University.

Once when we travelled you wore a key about your neck. People would stop and ask you what it opened your heart, your home, the centre of the earth - but you insisted it was just a key that opened nothing extraordinary. Only to the Japanese waiter in the crypt at St Martin in the Fields did you allow any concession. When he asked if he might use it, you answered perhaps.

(from Pulse 2016) 


\section{Bath Spa University}

\section{Carrie Etter}

Prose poems, written by members of the Prose Poetry Project, November 2014 to July 2017, compiled by the editors

Biographical note:

Carrie Etter is an American poet resident in England since 2001. Her poetry collections include The Tethers (Seren, 2009) and Divining for Starters (Shearsman, 2011). Her collection Imagined Sons (Seren, 2014) was shortlisted for the Ted Hughes Award for New Work in Poetry from The Poetry Society. She is Senior Lecturer in Creative Writing at Bath Spa University.

Call it a restricted diet: wild blue lupine. The caterpillars must have its leaves or. (In the mind's eye, plant the fields.) The caterpillars ingest the blue. To unfold. Break the chrysalis with thinnest wings. (Plant the fields.) Tremulous life.

(from Pulse 2016) 


\section{Niloofar Fanaiyan}

Prose poems, written by members of the Prose Poetry Project, November 2014 to July 2017, compiled by the editors

\section{Biographical note:}

Having lived in the US, the Netherlands, Tanzania, and then in Canberra, Niloofar Fanaiyan has recently completed a $\mathrm{PhD}$ in creative writing at the University of Canberra, and now lives and works in Haifa, Israel. She writes poetry and short fiction.

They are all reflecting - a circle of mirrors breathing, fingers resting, frames of golden filigree - they take turns keeping the light, the smoke weaves around and between, tinged with cardamom from the morning's coffee - the frames dance to the bells and drums and chaos of traffic below - watch the waves rise and approach, watch an arrow of birds pierce the wind, watch the light blaze and blaze again, watch the reflectors watch the world watching

(from Tract 2017) 


\title{
University of Canberra
}

\author{
Ross Gibson
}

Prose poems, written by members of the Prose Poetry Project, November 2014 to July 2017, compiled by the editors

Biographical note:

Ross Gibson is Centenary Professor in the Faculty of Arts \& Design at the University of Canberra. His books include 26 Views of the Starburst World (2012), The Summer Exercises (2008) and Seven Versions of an Australian Badland (2002). His most recent book of poetry, Stone Grown Cold (2015), is published by Cordite Books.

Mostly, you'll have to learn as you go. But here is information that might help you through the first days:

Luck can fall from the sky. But don't presume that it's all good luck.

The most popular song on the jukebox is something histrionic by Mister Roy Orbison.

'Shanti' is a word from an old Eastern scripture. Keep it available in your mind so it can serve your emotion.

The client will presume that there is nothing here - NOTHING - that is banned from importuning. This is regardless of whether or not the thing has a name. I mean, some other name, different from 'thing'.

There are nights when the rain hits the roof with a rhythm that's Cuban.

If ordered to use the knife, go at the task just like it's regular chicken.

(from Seam 2015) 


\title{
Griffith University
}

\author{
Stephanie Green
}

Prose poems, written by members of the Prose Poetry Project, November 2014 to July 2017, compiled by the editors

Biographical note:

Stephanie Green is a cultural historian and creative writer. Her most recent publication is The Public Lives of Charlotte and Marie Stopes (Pickering \& Chatto, 2013). She is also the author of Too Much Too Soon (Pandanus Books, 2006), a collection of short stories, and a widely published essayist. She is Deputy Head of School in the School of Humanities at Griffith University.

To start again is the hardest thing, to leave behind the pock marks of memory. I think of the time I left you on the side of a road to thumb your way from east to west. There were three letters that year, each one grimy and creased from where you carried them too long. I think of the first time you came to meet my train, unexpectedly, and I had already left the station. I waited for you on the steps outside your apartment with the smell of cannelloni beans cooking somewhere nearby. There was one other time, at the airport, when you went to the wrong terminal, but I waited knowing you would come.

(from Pulse 2016) 


\section{University of Western Australia}

\section{Charlotte Guest}

Prose poems, written by members of the Prose Poetry Project, November 2014 to July 2017, compiled by the editors

Biographical note:

Charlotte Guest is a Western Australian writer and Publishing Officer at University of Western Australia Publishing. Her first collection of poetry Soap was published in 2017 by Recent Work Press.

A cygnet was brought in from the lake today, its neck broken by a pure bred dog. I read about the bird in the blue room. I hear swan song, a keening that rises from the disco city and the silver banks beyond it. The journalist is blue and underpaid. Where, she writes, did the rushes go? The freeway casts shadows on my blue room walls. I read somewhere the world itself is residue. The sound of blood in transit is oceanic - I am small again, holding a shell to my ear. The cygnet was buried; the dog put to sleep. Cold stars turn on at the end of blue days.

(from tract 2017) 


\section{Leeds Trinity University}

\section{Oz Hardwick}

Prose poems, written by members of the Prose Poetry Project, November 2014 to July 2017, compiled by the editors

Biographical note:

Oz Hardwick is a poet, writer, photographer based in York, UK. In the guise of Prof Paul Hardwick, he is Programme Leader for Creative Writing at Leeds Trinity University, where he also teaches Medieval Literature. Most of the time, these conjoined identities get along just fine.

Stepping stones bleach in the indifferent sun, become mountains, crack to scree and, finally, sand. Frogs make way for lizards, rocking, throwing shapes in their jerkysmooth dancing. I see it all in the space of one deep drag on my first cigarette in three years, seven weeks, and two days. I'd add the minutes, but already a few ribs and the skull of some horned animal - cow? ox? - have appeared, barely casting a shadow. I flick the butt to anywhere and try to remember water: the sun's noon-high, and doesn't look like moving.

(from tract 2017) 


\section{Dominique Hecq}

Prose poems, written by members of the Prose Poetry Project, November 2014 to July 2017, compiled by the editors

Biographical note:

Dominique Hecq grew up in the French-speaking part of Belgium. She holds a $\mathrm{PhD}$ in Australian literature and an MA in literary translation. Dominique is the author of a novel, three collections of short fiction, five books of poetry, two plays and numerous scholarly publications. Her work has been awarded a variety of prizes, including the inaugural AALITRA Prize for Literary Translation from Spanish into English (2014). Her poems and stories have been published in anthologies, journals and on websites in Australia and overseas. Her papers have contributed to redefining a poetics suited to creative writing research that makes use of psychoanalytical concepts. Towards a Poetics of Creative Writing (2015), for example, explores creative writing in the academy as an avenue for investigating creativity while considering the relevance of psychoanalysis for the arts. Hush: A fugue (2017) is her latest book of poetry.

Her nom de plume was Gravity. She wore the hues of the sky and the sea as others wear a drop of lilac scent. She swore by the laws of that oceanic feeling and deep down knew far more than Einstein could have guessed at, attuned as she was to the chirp-chirping of the universe before the beginning of time. Just imagine how light she was and is and will be in the mass of our galaxy and in the masses of black holes in the centres of galaxies that keep spiralling around and around, and out. 


\title{
University of Canberra
}

\author{
Paul Hetherington
}

Prose poems, written by members of the Prose Poetry Project, November 2014 to July 2017, compiled by the editors

\section{Biographical note:}

Paul Hetherington is Head of the International Poetry Studies Institute (IPSI) and Professor of Writing in the Faculty of Arts and Design at the University of Canberra. He edited three volumes of the National Library of Australia's fourvolume edition of the diaries of the artist Donald Friend and is founding coeditor of the international online journal Axon: Creative Explorations. He has published ten full-length poetry collections, most recently Burnt Umber (UWA Publishing, 2016).

That night I held you in the shower - a grown woman, ill, naked, with a broken bowl's shards in your hair. Semi-conscious you leaned against me and I remembered your weight, a few weeks old in my free left hand, as if afloat on fingers; as if magic-carpeted on air. The weight was the same, reaching through my body with love's ceaseless amplitude, holding in my fingers as they combed out glass. The shower joined us, as when you were young, lying on your mother's belly in a furred rumination of light.

(from Seam 2015) 


\title{
University of Canberra
}

\author{
Penelope Layland
}

Prose poems, written by members of the Prose Poetry Project, November 2014 to July 2017, compiled by the editors

Biographical note:

Penelope Layland is a doctoral student in poetry at the University of Canberra. She has published two books of poetry: The Unlikely Orchard (Molonglo Books) and Suburban Anatomy (Pandanus Books). She has worked as a journalist, speechwriter and as a communications professional.

I'm planting for the next people now, hoping they'll believe this has always been so 'cottage-garden', so carelessly crafted. The clay will squeeze the annuals upright long enough for the auctioneer's hammer, the pungent mulch freshly shovelled should disguise the exhaustion beneath.

When did I grow so bored with it all? Windflowers bobbing and bearded irises; cuttings gift-wrapped in gladwrap by a mother-in-law; bulbs in brown paper bags in the fridge; seeds, small as dust, catching in the corners of their paper packets; sticky forget-me-nots, not forgotten, just neglected to death. Now, I am strenuous. Next autumn, when the first early frost crisps the lawn yellow, a stranger's child will slip, running unknowing for the swing that hung from someone else's ancient plum, the one we cut down to make way for the deck we did not use.

(from tract 2017) 


\section{Falmouth University}

\section{Rupert M Loydell}

Prose poems, written by members of the Prose Poetry Project, November 2014 to July 2017, compiled by the editors

Biographical note:

Rupert Loydell is Senior Lecturer in the School of Writing and Journalism at Falmouth University, the editor of Stride magazine, as well as a writer, publisher and artist. Shearsman recently published Dear Mary, a book of poems about Italy, colour, art, and annunciation; other critical writing has appeared in Punk \& Post-Punk, Journal of Writing and Creative Practice, New Writing and Journal of Visual Art Practice.

Down the lane, just yards from the main road, another small mews, its bright cottages all fitted out with grilles and shutters.

The same galleries in the museum I visited as a child: aeroplanes strung from the ceiling, a raised walkway to peer into the cockpits, a model of a water-raising device that appears to defy gravity, irrigates a miniature desert.

They are having to waterproof the pavilion, fill in the gaps with perspex, to deal with the unexpected sideways rain.

The vista of the park is cubed and squared, gridded; this is a building that lets in both light and air.

I count the sheep grazing in the pasture. I count the missing dead who they say are now living in paradise.

(from tract 2017) 


\title{
University of Gloucestershire
}

\author{
Nigel McLoughlin
}

Prose poems, written by members of the Prose Poetry Project, November 2014 to July 2017, compiled by the editors

Biographical note:

Nigel Mcloughlin is Professor of Creativity and Poetics at the University of Gloucestershire. He is a prize-winning Northern Irish poet with five collections of poetry in print - including Disonnances (bluechrome, 2007) and Chora: New and Selected Poems (Templar, 2009).

Water-star moves to the rhythm of a boat on a newmoon tide. Summer slices its way over the Atlantic to the shore. What sun there is slowly works its way across one side of my face as I stand fishing. I like the movement and the stasis of it, the alternating cast and return breathing a line across the channel, the tide too lazy to come back from the slack. I measure afternoon and evening by the dull punctuations of the fish that roll or splash just a little too far out. All the gulls have deserted me for other silences that require breaking; the seal turns its back and swims away. Venus and Jupiter twin themselves somewhere out on the horizon. I am content that every star should find its own declension.

(from Pulse 2016) 


\title{
University of Winchester
}

\author{
Andrew Melrose
}

Prose poems, written by members of the Prose Poetry Project, November 2014 to July 2017, compiled by the editors

Biographical note:

Andrew Melrose is Professor of Children's Writing at the University of Winchester, UK. He has over 150 film, fiction, nonfiction, research, songs, poems and other writing credits, including 33 scholarly or creative books. He is currently working on The Boat, an extended poem, book and exhibition about people migrating to safer countries on boats. See http:// theimmigrationboat-story.com

Dog tired from the nightshift, shoulders slumped and weary, but when he unslung his pit bag and coat, his strong arms opened to let us in.

(from Pulse 2016) 


\section{University of Canberra}

Paul Munden

Prose poems, written by members of the Prose Poetry Project, November 2014 to July 2017, compiled by the editors

Biographical note:

Paul Munden is Postdoctoral Research Fellow (Poetry \& Creative Practice) at the University of Canberra. He is General Editor of Writing in Education and Writing in Practice, both published by the National Association of Writers in Education (NAWE), of which he is Director. Analogue/Digital, a volume of his new and selected poems, was published in 2016.

His old green notebook falls open, seemingly at random. On facing pages - the draft of a poem and its later version, about a quarryman who tapped a block of limestone and eased apart the two halves to reveal the print and cast of a dinosaur footprint. On one page his father buys him a lemonade and the quarryman a pint, then loads the heavy slabs into the Vauxhall's boot. In the next there's his father's empty chair by the stone hearth, a yellow-brown patch on the ceiling.

(from Seam 2015) 


\begin{abstract}
Alvin Pang
Prose poems, written by members of the Prose Poetry Project, November 2014 to July 2017, compiled by the editors
\end{abstract}

\title{
Biographical note:
}

Alvin Pang is a poet, writer and editor based in Singapore, but active in literary practice worldwide. Among his many engagements he is a member of the IPSI Advisory Board. Author of over a dozen books, his poetry has been translated into more than twenty languages.

Those who don't know history are condemned to repeat it. Those who know history are condemned to watch it being repeated. Those who watch repeats can mutter along with the words. Those with watches can tell time. History isn't about time, and it's about time somebody knew that. There's a history of those who repeat condemnations. History repeats those who don't know. Replete with history, those who condemn are doomed. History is who knows? It repeats.

(from tract 2017) 


\section{Australian National University}

\section{Maggie Shapley}

Prose poems, written by members of the Prose Poetry Project, November 2014 to July 2017, compiled by the editors

Biographical note:

Maggie Shapley is a Canberra poet and University Archivist at the Australian National University. She won the 2003 ACT Writers Centre Poetry Award and her poems have been published in literary journals, anthologies and on Canberra buses as co-winners of the Poetry in Action Prize 2007 to 2009.

In the room with mirrored walls, we danced with words, catching sunlit glimpses of ourselves as we sashayed and side-stepped and spun. Exuberance spent, we stepped out on the terrace to test our phrasing, the humid air held us close till words found their right places, and the sky widened with the possibility of other rooms, of abundant gardens to explore on other days. Out of the silence the bright murmur of your voice, 'I am here, I am here, I am here', a string of amber beads around my neck.

(from Pulse 2016) 


\section{University of Winchester}

Julian Stannard

Prose poems, written by members of the Prose Poetry Project, November 2014 to July 2017, compiled by the editors

Biographical note:

Julian Stannard taught English and American Literature at the University of Genoa and currently teaches English and Creative Writing at the University of Winchester. His most recent collections are The Street of Perfect Love (Worple Press, 2014) and The Parrots of Villa Gruber Discover Lapis Lazuli (Salmon Poetry, 2011).

When he sat in restaurants Zac wrote poems on paper napkins. Poems were like the change in your pocket. Unlike Emily Dickinson, Zac wanted to escape into prose. When he'd first stepped into the mansarda in The Street of Perfect Love he'd felt compelled to write something that had little to do with poetry as he usually thought of it. He didn't have much patience for notions of automatic writing but he had to admit that there was a certain compulsion about his more recent literary endeavour. When he sat down at the long table in that large, sunlit apartment the typewriter hardly ever seemed to snag.

(from Seam 2015) 


\title{
University of Canberra
}

\author{
Shane Strange
}

Prose poems, written by members of the Prose Poetry Project, November 2014 to July 2017, compiled by the editors

\section{Biographical note:}

Shane Strange is a doctoral candidate in writing at the University of Canberra where he also tutors and lectures in writing and literary studies. His research interests include creative labour and cultural work; subjectivity and creative practice and cultural representations of the city. He is a writer of essays, short fiction and creative nonfiction and now, prose poetry.

Water. Always trickling in my ears like the leavings of a fountain. It pools in my eyes when I sleep. I step across empty baths in winter. I pick old bicycles from the river, and shopping trolleys, and rusted anchors from mud flats when the tide goes out. I search puddles for tadpoles. In summer I watch dragonflies hovering over stagnant ponds hoping they don't drown. Mother told me never to fill the bath above the knuckle of your finger. And a cup of water's all that's needed to wash the plates. She drank from thimbles and trembled at waterfalls. We are mostly water, I told her one day. That made her shiver for a week. The rain gets in now, in the corner of the room, and the plaster is coming away from damp. I find my fingers pruning in dry air, a stream running down my back, and a dripping on my forehead. I hear the ocean when I dream. The waves coming in and rolling over me and taking the smallest piece with them, and again and again and again.

(from tract 2017) 


\section{University of Canberra}

Jen Webb

Prose poems, written by members of the Prose Poetry Project, November 2014 to July 2017, compiled by the editors

Biographical note:

Jen Webb is a writer and cultural theorist, and Director of the Centre for Creative and Cultural Research at the University of Canberra. She writes poetry, researches creative practice, and makes and exhibits artist books. Her most recent books are Watching the World (with Paul Hetherington) (Blemish Books, 2015) and Researching Creative Writing (Frontinus, 2015).

After the apocalypse we sent in the dogs. First responders, sounding the air. They moved across the city, finding the signs, barking, beginning to point. Below them, cell calling silently to cell, lay the living. All day the dogs kept watch as we hauled rocks and scraped at the soil, fingers bleeding, shovels blunt. We pulled a child from where the school had been; a nun from the church. Three or four others we lifted from the heart of stone. We worked all day, pouring water on our heads, coughing up dust, the dogs urging us on, til they ran out of things to say. When evening came, they fell silent, and walked away, their tails held low.

(from tract 2017) 


\title{
University of Canberra
}

\author{
Jordan Williams
}

Prose poems, written by members of the Prose Poetry Project, November 2014 to July 2017, compiled by the editors

Biographical note:

Jordan Williams is Associate Professor of Writing at the University of Canberra. She pursues an ongoing interest in the future directions of reading and writing including new forms such as new media writing as well as the growing popularity of older forms such as the graphic novel, and the nexus between fiction and nonfiction.

She woke crying desolately to find the door open, windows wide and her dream sitting in a chair staring at her. Why do you do this, he asked her, as his black tongue licked his black pudding lips. She thought it a good but obvious question but not one she could answer under pressure of the breaking dawn and the bull roaring in a nearby field. I'm not supposed to have men in my room, she hissed and this was enough to make him run, like all cowards who don't really want the answer. This much she knew.

(from Seam 2015) 